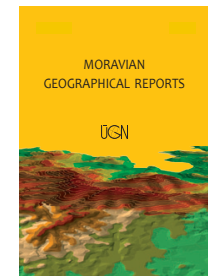

\title{
The role of the novel in shaping a city's image and its choice as a tourist destination: The case of Łódź
}

\author{
Bogdan WŁODARCZYK ${ }^{\text {a }}$, Michał DUDA * *
}

\begin{abstract}
Following in the footsteps of one's favourite literary characters has become a significant part of tourism. It remains unknown, however, how many readers decide to visit the places described in a book, or what factors determine their decision to do so. This issue was analysed using the example of Łódź, the third largest city in Poland, which struggles with a negative image. In contrast to the research on literary tourism conducted so far, a questionnaire was completed by readers and not by tourists visiting the places described. The readers remembered many real locations and had become familiar with the city's topography. Some declared their reluctance to accept its stereotypically 'bad' image, while others were fascinated with its 'unique atmosphere'. To many the city has become more familiar and a significant number of readers have changed their perception of it as a result. By means of linear modelling, several factors were established which encouraged readers to visit the city for tourism purposes. These factors included the size of the reader's home location, changes of opinion, and the first impression the book made. This research project clearly points to the significant role of the novel in creating images of the places it depicts.
\end{abstract}

Key words: literary tourism, tourism, crime story, city image, Łódź, Poland

Article history: Received 25 July 2018, Accepted 6 March 2019, Published 31 March 2019

\section{Introduction}

Literary tourism is a component of cultural tourism which has become a common phenomenon over several recent decades. Following in a writer's footsteps or travelling to places described in a book, can be either an element of or the sole aim of a tourist trip. Until the present, research has usually been concerned with the space created by the writer or has been conducted among tourists directly at the literary reception site. Using such approaches, researchers did not study the influence of literature on the readers in the context of choosing a tourist destination, focusing only on those who had made such a choice. They did not consider all the readers of a specific publication. Reijnders (2015) believes that with this approach, there is a risk that the emotions and experiences of travel will overshadow the memories of the stage when decisions were being made, and that the study will include only 'successful' cases of the influence of literature.

We present another approach to these issues: to include research conducted among readers who are only potential literary tourists. This comprises the latest novel by a renowned Polish author of crime stories, Katarzyna Bonda (2016), and it is set in Łódź, the third largest Polish post-industrial city, currently experiencing depopulation problems and negative images. The book which is analysed here is in fact the second novel - after 'The Promised Land' by the Nobel Prize winner, Władysław Reymont ${ }^{1}$ - to be so strongly related to Łódź. The city is more than just the background in this novel: it is an important protagonist, because the author herself emphasises that it's a novel about a place. This results in quite an accurate depiction of 'reality' in the book, in terms of spatial, historical and cultural contexts.

As researchers, we focused on the influence of the book on perceptions of individual elements of the city, analysing the associations and remembered places, as well as enquiring about willingness to visit the city after reading it, which is most significant from the point of view of tourism organisers. The results obtained are the starting point for a consideration of the role of literature in the promotion or marketing of a place, as well as an example of literary tourism in the context of the tourism potential of a city.

\footnotetext{
${ }^{a}$ Institute of Urban Geography and Tourism Studies, University of Lodz, Poland (*corresponding author: M. Duda, e-mail:michal.duda@unilodz.eu)
}

\footnotetext{
${ }^{1}$ Reymont was a Polish novelist and Nobel Laureate for Literature in 1924.
} 
The aim of the paper is to establish to what extent a novel shapes the image of a city and motivates the reader (potential tourist) to visit it, as well as what features (of both the book and its reader) are determining factors. This research project clearly points to the significant role of a novel in creating images of the places it depicts.

\section{Theoretical background}

\subsection{Literary tourism - characteristics}

Literary tourism is a very old phenomenon, probably dating back to the early history of the written word, and the first journeys to writers' graves were made in Antiquity (Smith 2012). This phenomenon, however, concerned only a small number of people because of the rarity of literature, rates of illiteracy, the cost of books and the amount of free time, as well as the cost of such journeys which could be afforded by few. To a certain degree, we may regard the famous Grand Tour (Adler, 1989; Towner, 2002) and Petrarch's journeys as literary travel. The latter are considered by Hendrix (2009) to be the first fully organised literary trips. Another example is the $19^{\text {th }}$ Century journeys to sites from popular novels, legends and myths in Great Britain (Watson, 2006; Ellis, 1989, 2001).

In recent decades, travel related to literature has become increasingly popular. A commonly accepted definition of literary tourism was proposed in 1986 by Butler (2000), who stated that its main purpose was to reach specific places related in various ways to literature. Such travel may entail visiting the present and former homes of writers and poets' and true and imaginary places described in literature, as well as places referring to literary characters and events. A similar definition of literary tourism was proposed by Busby and Klug (2001, p. 319), who claimed that it takes place when "the popularity of a literary depiction or the stature of an individual author is such that people are drawn to visit the places that he/she wrote about or was associated with." Stasiak (2009) divides literary tourism into two categories: biographical tourism (where the destinations are places connected with writers); and literary fiction tourism (including, for instance, visiting real and fictional settings of books, reading literature outdoors, staging theatrical events, workshops, summer schools, theme parks, etc.).

Thus, literary tourism is a part of cultural tourism, which is defined (after WTO, 2005, p. 9) as "all movements of persons to specific cultural attractions, such as heritage sites, artistic and cultural manifestations, arts and drama to cities outside their normal country of residence. In order to structure the way cities can be looked at as destinations for cultural tourism a framework has been developed based on the predominant (cultural) product of a place and the type of place, such as village, town, city and metropolis." This domain of tourism is developing very rapidly and, as UNWTO reports, became a significant part of cultural tourism (Mintel, 2010, 2011; Mansfield, 2015; Jiang and $\mathrm{Xu}, 2017)$. Unfortunately, it is difficult to establish what percentage of cultural journeys are those which could be regarded as literary tourism. Many examples from the literature, however, point to the growing significance of literary travel. A strong relationship between literature and tourism was visible in the interviews conducted by Reijnders in 2015, where over half of the respondents declared their willingness to visit places they knew from their 'beloved' tales. Watson (2006) even claims that in Great Britain literary tourism has gained the status of a commercial phenomenon. A good example is the story of Dracula, which is the main attraction drawing tourists to Romania (Light, 2007). He is a fictional character who the Romanians themselves do not like, as it depreciates the historical figure that Dracula was modelled on. It is still, however, the foreigners' strongest association with this country, which is an excellent foundation for creating tourism products (Cosma, Pop and Negrusa, 2007).

The huge tourism potential 'hiding' in literature can be the consequence of a variety of reasons. The reader who is not familiar with the place they are reading about, often wants to experience the world created in the novel by travelling to the real places described in fiction. This blurred boundary between fiction and reality is fundamental to making decisions on visiting such a place (Andersen and Robinson, 2002). Readers often identify themselves with the characters, want to have similar adventures and delight in similar views. If the novel interests the reader, they spend long hours with it and in this way they 'enter' the literary world, which (apart from the fictional plot) is realistic and is not difficult to visit. Reijnders (2011) remarks that 'places of the imagination' offer fans the possibility of having a transcendent experience between two worlds: an imagined world on the one hand and that which is considered to be the 'real' world on the other. In this way, the reader who travels to places described in literature may 'experience' a substitute of the story that fascinated them.

\subsection{International examples of literary tourism}

There are numerous examples of literary tourism taking advantage of places connected with the lives of renowned writers or places where their stories are set, and every country has tens or hundreds of them. For instance, William Shakespeare attracts over 4.9 million tourists annually to Stratford-on-Avon (the town where he was born, with only 25,000 inhabitants). The same concerns his writings: Hamlet attracts people to the castle of Kronborg in Denmark and Romeo and Juliet is the basis of the tourist industry in Verona, Italy (Stasiak, 2009). In Europe, people visit places described in the novels by James Joyce (Dublin from Ulysses), Mikhail Bulhakov (Moscow from The Master and Margarita), and Arthur Conan-Doyle (Sherlock Holmes). The cities which attract tourists interested in great writers include, for instance, Prague (Kafka), Florence (Dante), Paris (Moličre), Weimar (Goethe) and hundreds of others (Stasiak, 2009).

The latest examples include Scandinavian crime stories, such as Stieg Larsson's books, attracting tourists to Stockholm (following in the footsteps of the characters was announced as the best literary trip in the world by Lonely Planet Publishing in 2014), or the writings of Henning Mankell, popularising Ystad in Sweden through the character of Inspector Kurt Wallander; trips following the trails in Dan Brown's novels (Rome, London, Paris, Florence, Bilbao, Barcelona: Skyscanner, 2009); or a journey around New Zealand, inspired by the film adaptation of The Lord of the Rings and Hobbit by J.R.R. Tolkien (Li, Li, Song, Lundberg, and Shen, 2017). The National Geographic magazine (2011) lists St Petersburg, Portland, Melbourne and Santiago among 'the most literary cities of the world'. Some literary references are often used to promote whole regions, such as the 'Catherine Cookson Country' in Northumberland (Herbert, 2001), 'Shakespeare's Stratford', 'The Brontes' Yorkshire', and 'Hardy's Wessex' (Squire, 1994). Ryan, Yanning, Huimin 
and Song (2009) suggest that evidence exists that novels, films, and television series can and do attract visitors to destinations, but the record of increasing visitor numbers states little about what it is that actually motivates them. The examples presented above show that the location of a novel's setting may cause greater interest among readers and encourage them to make a tourist visit.

\subsection{Polish examples of literary tourism}

So far, in Poland, no city has been able to create a coherent tourist product based on literature, despite many individual activities and small undertakings (Pudełko, 2015). In several Polish cities, tourist trails have been created, following the traces of characters from novels (mostly crime, e.g. Eberhard Mock's trail in Wroclaw and the trails following crime stories set in Krakow). There are also several museum exhibitions dedicated to writers or literary characters. In recent years, many successful books have been made into films (e.g. Miłoszewski's crime stories). The most popular form of promoting a city by referring to famous novels is a thematic walk (e.g. in the company of the author) and urban games (there have already been several dozen organised in Poland) (Pudełko, 2015).

Nevertheless the authorities of Polish cities hardly ever woo the writers or ask them to place the city in their story. There are two exceptions to this: a literary competition in the town of Piła for the best crime story set there ('piła - in English 'jigsaw', which makes the name of the competition 'Criminal Piła' - a witty pun, as it can also be read as 'Criminal Jigsaw'). The other exception is the festival in Wrocław with its annual competition for the best short story related to it. In both cases the winners can publish their writings as a prize (Pudelko, 2015).

\subsection{Similarities with film tourism}

Such undertakings, however, cannot be compared to the global trend called 'set-jetting' (the term was first used in 2008 by Gretchen Kelly in an article for the New York Post, and it means 'travelling to film sets'). Several decades ago people working in the tourism industry had already realised the value of location in films and tried to have some influence on this process. For instance, film directors and producers are informed about the chance to take unique shots at a specific place which is to be promoted (Kavaratzis and Ashworth, 2006), which is then treated as an effective form of advertising. Examples which we can quote here include the famous films by Peter Jackson, The Lord of the Rings cycle, Woody Allen's series of films set in European capitals (Reijnders, 2015), the promotion of Scotland in Braveheart, and the current tourism boom in Dubrovnik from the Game of Thrones (Martin-Jones, 2014, Rodriguez, 2015).

In comparison to film tourism which is based on the director's vision, where the spectator is provided with a view of the setting, in literature it is the reader who creates the final visualisation. According to Watson and Saunders (2004), it is the reader who interprets the words written by the author into their own vision of reality and actually 'generates' the place, not the writer. A place interpreted in such a way has greater, even intimate, significance for the reader, who becomes strongly attached to it. Thus, place plays a very important role in literary tourism, particularly in literary fiction tourism. Writers may create and define space anew through their works, and literature can reflect the real place and how it is used (Andersen and Robinson, 2002).
Even if literary tourism differs from that inspired by films, the suggested marketing tool (promotion via cultural elements) (Hudson and Ritchie, 2006) can be adapted to literary tourism, in which authors may actively promote individual destinations. In this way, such destinations may be positively distinguished from competing places by being 'positively planted' in the minds of consumers, which may have an impact on the tourists' behaviour (Echtner and Ritchie, 2003; Pike and Ryan, 2004; Hudson and Ritchie, 2006).

\subsection{Research methods on literary tourism}

The phenomenon of literary tourism has been studied in a variety of ways and researchers often utilise interviews with tourists at the destination. This was what happened in the research conducted by Herbert at Chawton and Laugharne (Herbert, 2001), by Tetley and Bramwell at Haworth (Hoppen, Brown and Fall, 2014), and by Squire at the Beatrix Potter farm, Hill Top, in Cumbria (Squire, 1991). Dung and Reijnders (2013) conducted interviews with Chinese tourists, charmed with the image of Paris emerging from the media (literature, films and serials), in three stages: before arrival (pre-visit stage), during the visit (on-site stage), and after returning home (post-visit stage). The second most popular method of studying literary tourism has been the analysis of available source materials, such as Smith (2012) in South Africa, Cosma, Pop and Negrusa (2007) in Romania, Wallace (2009) in Dublin, and many others. Most of these methods have one serious drawback, which was noted by Reijnders (2015): they consider the issue only in retrospect and ignore all 'unsuccessful' cases, when after reading a book, the reader decided not to visit the places it refers to.

Other studies have been concerned with the workers and organisers of literary tourism: for example, McGuckin (2015) conducted his research in places connected with Shakespeare; and Fawcett and McCormack (2001), in Canadian places connected with the writings of Lucy Montgomery. An original study method was used by Gentile and Brown (2015), who analysed this phenomenon using autoethnology: for two months, they personally collected information and recorded it in their notebooks to be analysed later. Most literary tourism studies have been carried out in Europe and North America (Hoppen, Brown and Fall, 2014), but in South Korea, in the home village of the popular writer Kim Yu-jong, who set some of his novels there, a trail and a museum were created, and the village was officially renamed Kim Yu-jong's literary village (Lee and Weaver, 2012).

Reijnders (2015) conducted fifteen in-depth interviews for the purpose of investigating the relationship between fictional stories (known from films, literature and tales) and making a decision about a travel destination. In his research, however, he did not focus on specific items of culture, but rather on the general process which precedes a tourist visit. An issue to consider and an inspiration to undertake research was the question whether 'city location' in literature can be used for tourist promotion in a similar way. In the research by Ryan, Yanning, Huimin and Song (2009), conducted among tourists visiting the gardens in Beijing, it was found that the novel which describes the site was extremely important for as many as $52 \%$ of visitors. It is a fact, however, that Lampiony is not a book written 'on commission', because the city authorities did not try to convince the author to choose Łódź as the setting. Still, it would be interesting to know whether such promotion could bring the results expected. 
Considering the lack of publications that focus on readers of a specific book who have not decided yet to visit its setting (potential literary tourists), it can be assumed with considerable certainty that this paper is likely to be one of the first of its type.

\section{The place and the book}

\section{1 Łódź as the spatial context of the novel}

Lampiony, Bonda's book set in the post-industrial city of Łódź, was not chosen accidentally. In contrast to most Polish cities, Łódź does not feature elements related to the medieval 'golden age' (no palaces, castles, stories about royalty, etc.), which are often the core of urban identity (Young and Kaczmarek, 2008). It struggles with many problems, such as depopulation, degraded urban fabric and many former industrial areas. It is negatively perceived by Polish people: in attractiveness rating, it often occupies low ranking positions, for example, The perception of provincial capitals (TNS OBOP, 2013) and The reputation of provincial capitals (Premium Brand, 2015). There are many stereotypes and unfair opinions, such as Łódź has been called the 'Polish Detroit' (Hall, 2014) or even miasto meneli (the city of 'bums') in the media and public discourse.

There are many reasons for such opinions, but they are mostly caused by the history of this city. Between 1825 and 1915 there was rapid population growth from around 1,000 to around 600,000 . The city had a multi-ethnic population with German textile entrepreneurs, workers and technical staff, Polish textile operatives, Russian administrators and Jewish entrepreneurs, traders and artisans (Young and Kaczmarek, 2008). Until 1900, Poles accounted for only 10 $30 \%$ of the city's population (Liszewski, 1997). The layout of the city was based on a division into plots for craftsmen and a grid of streets - hence a comparison to New York (the rapid growth observed in American cities, which also developed based on industry, was similar). The poorest workmen of the $19^{\text {th }}$ century factories lived next to the wealthiest inhabitants living in their lavishly decorated palaces in this part of Europe. As Young and Kaczmarek (2008) note, Łódź's industrial development led to its image becoming that of a 'bad city' and for some people it became synonymous with the exploitation of the working class. This identity was reinforced by the publication of Władysław Reymont's novel The Promised Land.

Such a cultural mixture had an influence on the Second World War history of the city, where the second largest Jewish ghetto was created (after the one in Warsaw). Because of the war, the city lost 430,000 inhabitants and became largely mono-ethnic (Marcińczak and Sagan, 2011). In the post-war socialist era, the city authorities did not care about or invest in the heritage left behind by the industrialists, for ideological reasons (Fleming, 2012). The authorities of that time continued the pre-war direction of development, focusing on the nationalisation of 1945 textile production. At the turn of the 1990s, this caused the most serious crisis in the history of the city as the loss of eastern markets in 1989 devastated Łódź's economy. The unemployment rate reached over 20\%. In addition to this economic crisis, Łódź was stereotyped as a grey, grimy, industrial city (Young and Kaczmarek, 2008). The unavoidable effect of the economic shift, manifested by the expansion of urban poverty, became a salient characteristic of the social reality of Łódź in transition (Marcińczak and Sagan, 2011). It was then that negative opinions became established; they are still present, despite the considerable changes for the better that have taken place in recent years.

For several years, Łódź authorities have been trying actively to change the negative opinions concerning all spheres of life. Initiatives attempting to enliven the city include the festivals: 'The city of colours' (painting grey urban building elevations); 'Dialogue of Four Cultures' (referring to the multicultural roots of the city); a promotional campaign 'We are inviting you to Łódź - it can also be your Promised Land', referring to the novel by Reymont; and, unfortunately unsuccessful, attempts to win the title of the European Capital of Culture 2012 (Young and Kaczmarek, 2008; Fleming, 2012). The city has the largest number of revitalisation programs in Poland: old, historical, $19^{\text {th }}$ century factories have been turned into luxury hotels, museums, shopping centres and cultural institutions. A wide-ranging program of reconstructing the City Centre was launched. Spacious woonerfs ${ }^{2}$ are appearing, and in 2016 the most modern railway station in Europe was opened. The city can boast the largest number of nineteenth century industrialists' palaces and villas in Poland (according to the Town Hall).

The difficult history of the city, the rapid changes it has undergone and the negative opinions about it held by inhabitants of other cities, make Łódź a good 'laboratory' for research on the perception, image and the confrontation of reality with what is imagined. Rapid development and 'reconstruction' improve its image year after year. This makes research even more valuable on how readers who have not visited Łódź (or only visited it a long time ago) imagine the city. The more so, considering the different problems, as the authorities are looking for an idea for promotion. While in cities such as Rome, London or Paris, the influence of books or films set there on the intensity of tourism may be insignificant, in 'non-tourist' Łódź, a novel of this kind may have a significant effect.

\section{2 "Lampiony": A book about the city}

The book Lampiony was chosen for other reasons as well, above all due to the popularity of the author, who is called 'the Polish queen of crime' by the media, and her books are compared to novels from the so-called 'Scandinavian school'. This makes every new novel widely known across the country and wins thousands of readers, and thus has a wide range of influence and does not remain a niche publication (unlike the majority on Łódź, apart from The Promised Land).

The book in question has received a major advertising campaign in Poland in recent years. Billboards (see Fig. 1) and large format advertisements appeared in the streets, while the promotion was visible in the press and on the Internet. For the first time in Poland, the promotion of a novel involved opening a bookstore with only one title. In Warsaw, for one day (the launch), on $27^{\text {th }}$ September 2016, a Lampiony pop-up store was opened with 10,000 copies of the novel. For a whole day, the author was present, signing her books and answering questions. After the launch, walks with guides were organised in Łódź following in the footsteps

\footnotetext{
${ }^{2}$ A 'woonerf' is a living street, as originally implemented in the Netherlands, include shared space, traffic calming and low speed limits.
} 
of the characters from the novel, as well as an urban game. Towards the end of 2016, a theatre spectacle was staged based on the Lampiony story (Fig. 2). Such huge promotion of a novel featuring Łódź had never taken place in the history of the city before. The large number of readers allows us to assume that the book became a very significant element in creating the city's image. Thus, the research interest to study in what ways reading the book influences opinions about the city was intensified.

It is an important fact that this crime story is, in the author's words, "a novel about the city" (Bonda, 2016, p. 629). In the afterword, she writes:

'the setting of my books is a key issue. (...) the story narrated in Lampiony could happen only there. Nowhere else does the light shine like there, or will you find such energy, hear so much cursing, see bottles in gateways, feel such longing for the past, but at the same time meet so many unusual, open, warm and helpful people in the streets. (...) Every walk along Łódź streets is like a scene from a film. (...) Nothing is smooth or slick, as if from a postcard here. (...) Standing next to one another, in full harmony, there are glass-clad high-rise buildings, historical tenement houses, the districts of the poorest and the artists, and kebab shops. All this is saturated with the spirit of artists, from mural painters to the best rap musicians.' (Bonda, 2016, p. 630-631)

Before writing the novel, Bonda spent several months in the city discovering Łódź with the help of guides, fans, museum workers and local inhabitants. This resulted in the very realistic picture of the city presented in its pages. Whole sections resemble a guidebook, containing true descriptions of buildings, interiors and topography. The novel also contains a large number of elements specific to Łódź, starting from local vocabulary to song lyrics, references to literary works, music and films by artists and poets connected with the city. Lampiony features several dozen genuine locations, street names, tram and bus lines, and over 35 detailed descriptions. The writer touches upon the historical issues of the city, its famous inhabitants, as well as the causes of the crisis and the problems the city struggles with. This makes the novel an extraordinary crime story, here the setting is not just a background, it is one of the major protagonists. In this way, the combination of a popular fiction style with the qualities of a guidebook makes it ideal for research on the influence of reading on a reader's perception of the city. Furthermore, the date of publication (it is recent) makes it possible to observe the process of developing literary tourism, in this case, 'from the beginning'. All the factors mentioned above: popularity; promotion; a large number of readers; guidebook-like sections; and a real space as the setting, give the book the potential to build complex tourist products referring to it. The evidence that the city is strongly present in the story is the large number of specific places and sites described by the author (see Figs. 3 and 4).

The maps present 76 places, which are the basis for further analysis. Most descriptions (58) regard real places and sites and only eight are creations of the author's imagination, mostly including elements of 'underground Łódź' (shelters, tunnels, underground motorways) or the unfinished mosque. The majority (39 sites) are situated in the strict city centre (Fig. 4). The characters are found in 30 of these places, 26 are indirectly connected with the storyline while 20 ("none") have nothing to do with it. Sites included in the "none" category are those which were mentioned in the novel and have realistic location, but they are neither directly nor indirectly related to its plot (e.g. they are mentioned in a dialogue as an element of the cityscape). The analysis did not include surface areas (districts, quarters), linear areas typical of the city (e.g. rivers, sewers), nor those whose descriptions did not point to specific locations.

The level of accuracy in the descriptions of individual sites also varies. Complete and detailed descriptions concern less than a third, short for 20 , while 34 are just briefly mentioned. When analysing the content, we can notice that some descriptions represent a guidebook style of narration (history,

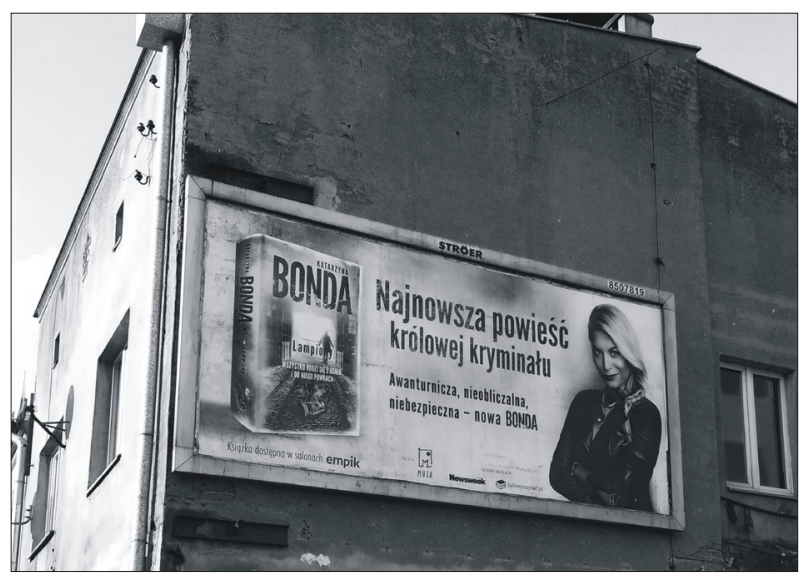

Fig. 1: A billboard advertising Lampiony on a tenement house. Content translation: "The newest novel of queen of crime. Adventurous, unpredictable, dangerous - new Bonda". Source: authors' photograph

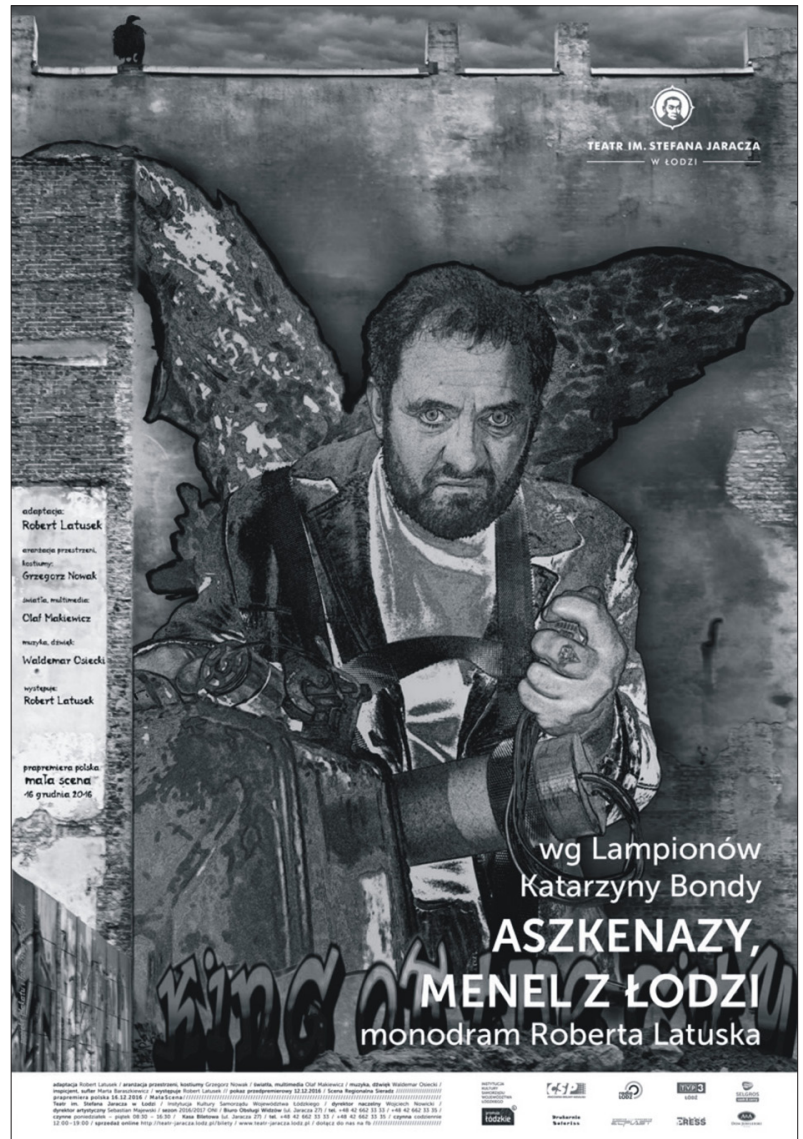

Fig. 2: A poster advertising a theatre spectacle using the motifs included in Lampiony.

Source: Grzegorz Nowak, advertising materials from Jaracz Theatre in Łódź 


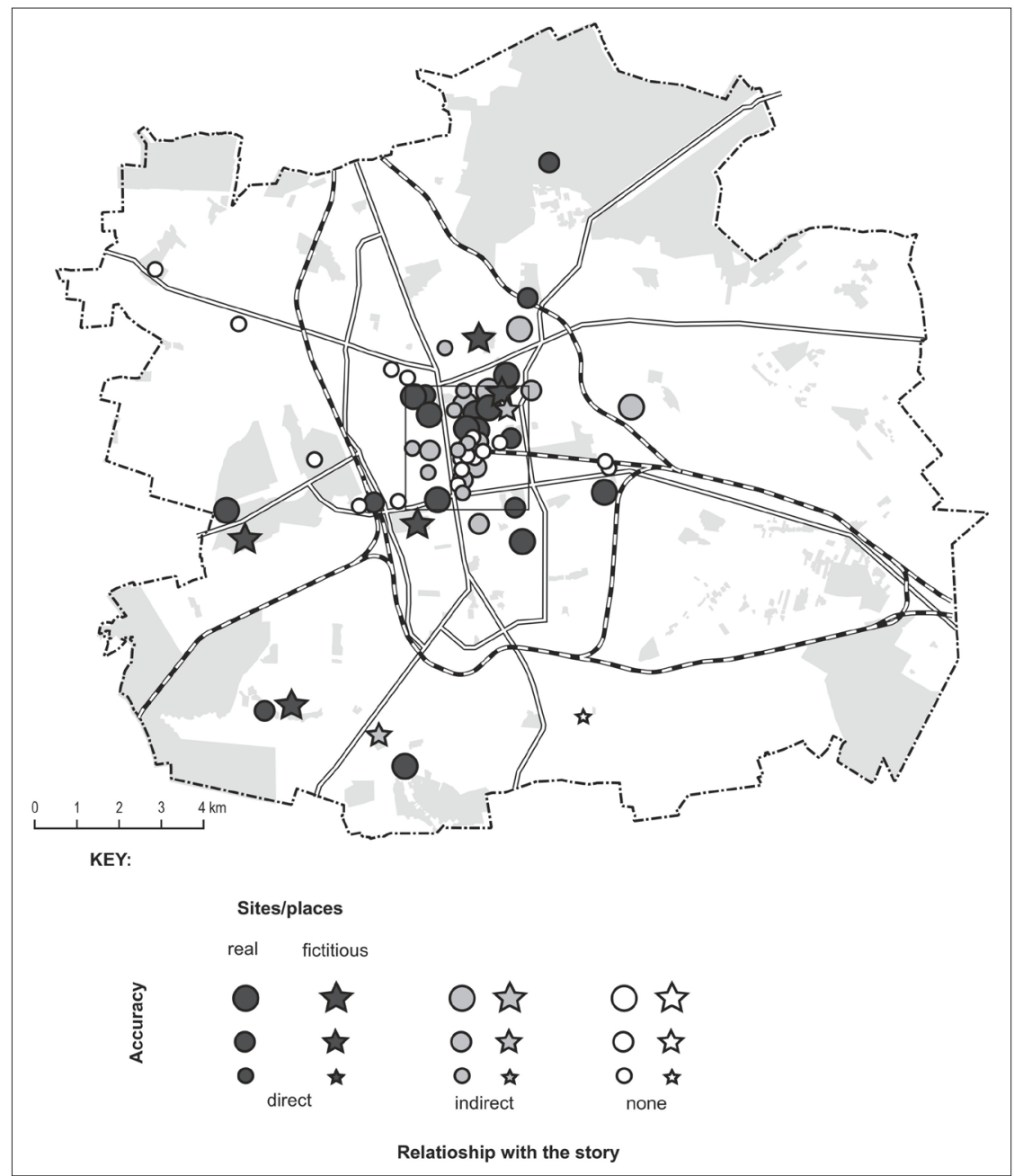

Fig. 3: Distribution of Łódź sites and places mentioned in Lampiony (Note: Grey areas = greenery (forests, parks), White areas $=$ urban areas). Source: authors' elaboration

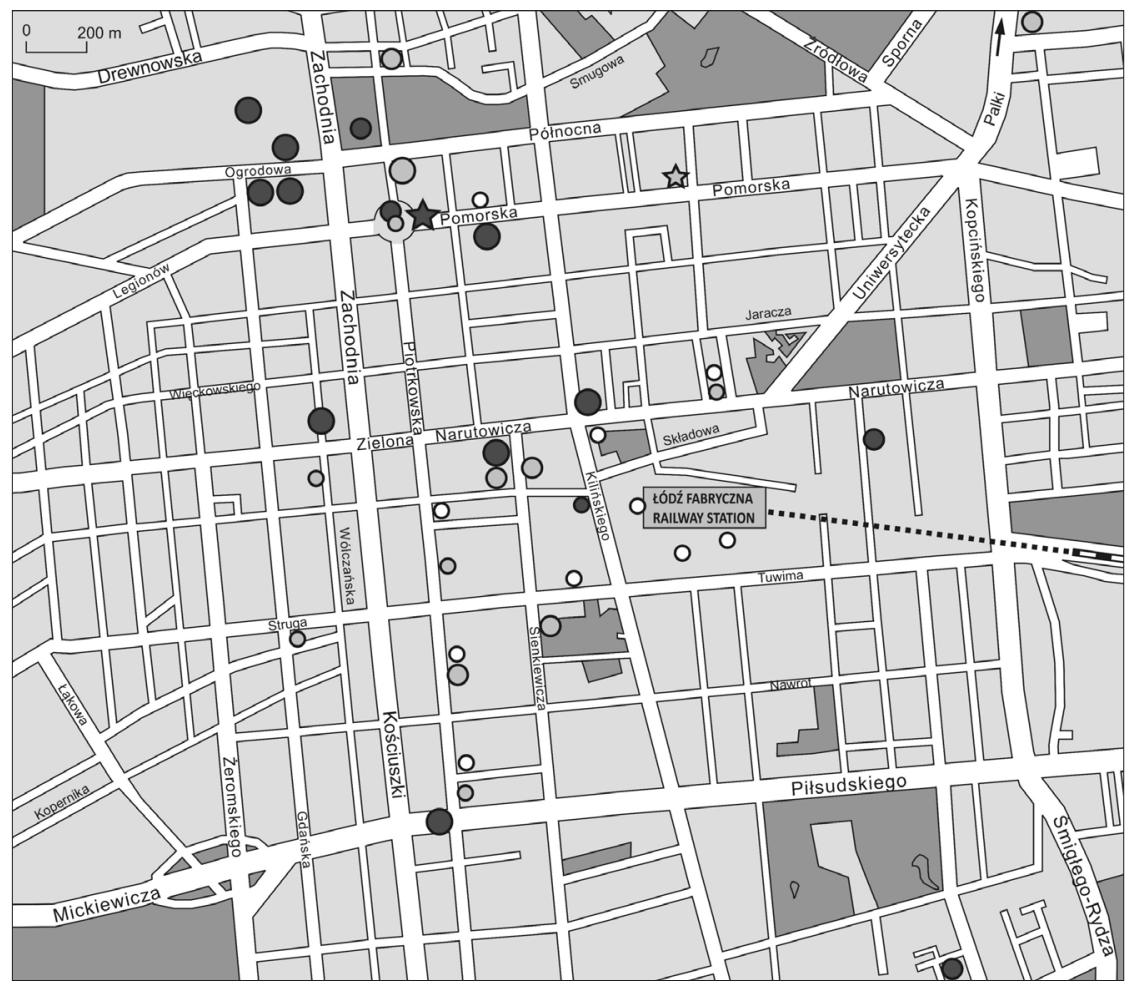

Fig. 4: Distribution of sites and places described or mentioned in Lampiony: The centre of Łódź (Key as in Fig. 1). Source: authors' compilation 
dates, architectural details and interesting facts). Literary techniques like this are usually evaluated as vague. On the one hand, the book becomes a source of information and an encouragement to visit the city, but on the other, the technique slows down the action and the guidebook-like descriptions seem artificial compared to other parts of the novel.

\section{Research methodology}

The research was conducted using a questionnaire distributed online. People who had read Lampiony were contacted through the portal entitled lubimyczytac.pl ('we like read', the largest Polish website presenting book reviews, enabling readers to have discussions, evaluate and express their opinions. It is also a social media platform for literature lovers. Currently, it has over 670,000 registered and active users (nearly $2 \%$ of Poland's population). The survey questionnaire was sent to a sample of selected users: the basic criterion of choice was indicating Lampiony as a book that had been read and then evaluating it in some way. Out of this group, the researchers selected those who had expressed an opinion and presented it as text. In this way, they chose people who were more likely to complete the questionnaire and more willing to provide answers to the open questions included. Overall, an invitation to take part was sent to 322 people, and 130 (40\%) respondents returned correctly filled-in questionnaires, which is a good result. This response rate may indicate some level of self-selection bias, but it cannot be controlled for in such a design. It is likely that the benefits outweigh the costs in such a case.

The research was limited to a study conducted via the Internet mostly due to the fact that the greatest difficulty was reaching people who might become potential literary tourists. Unfortunately, it is not physically possible to conduct interviews with those who have bought the book, neither the shops nor the publisher record their customers' data, nor are willing to pass it on. Buying a book does not necessarily mean reading it, either, especially in the period before Christmas when it was promoted and was often bought as a gift.

Respondents varied with respect to sex: 100 women and 30 men. This may have resulted from disproportionate reading habits in Poland [according to a report 'Stan czytelnictwa $w$ Polsce w 2015 roku' (in English: Polish readership in 2015) prepared by the National Library, $46 \%$ of women and only $27 \%$ of men read at least one book in a year]. Almost nine out of ten respondents $(86 \%)$ had university education, $10 \%$ secondary education and $4 \%$ only elementary or basic vocational. According to the report, this does not deviate from the norm in which the higher the level of education, the higher the percentage who read books. The most numerous group of respondents consisted of those aged $20-40$ years. The respondents (over 62\%) came mainly from large cities with over 500,000 inhabitants, and smaller towns $(23 \%)$, while another $15 \%$ lived in the countryside. These response patterns were probably due to the larger popularity of writing posts on Internet forums among city inhabitants, a higher rate of reading in urbanised areas, as well as the fact that the advertising campaign was run mostly on the streets of large cities.

The survey was conducted in November and December, 2016 , i.e. slightly over one month after the book's launch $\left(28^{\text {th }}\right.$ September 2016). As a result, it was fresh in the respondents' minds, but some time had already passed since reading the book, which eliminated the element of 'heated' emotions present right after finishing it, possibly influencing its reception. Out of the 130 who participated in the study, only 14 had read the book just a few days before filling in the questionnaire, 47 people had read Lampiony a week or so before, and 69 claimed that they had read it more than one month before. A very large majority $(92 \%)$ of the respondents came from outside Łódź, the city where the book is set. This is very important in the study because the respondents are potential tourists. What is more: $43 \%$ of them had never been to Łódź; and $24 \%$ had visited the city more than three years earlier, so their current image was not strengthened by personal experience. The inhabitants, or those who had visited the city in the previous year, made up $26 \%$ of the respondents, while $7 \%$ did not indicate any specific date of visit. Considering the aims of the research, the most important responses are those that were collected from people living outside the city and barely knowing it.

\section{Results}

\subsection{General impression of the city}

The first issue approached in the questionnaire was the respondents' general impression and feelings towards the city described in the book. They were asked to define their impressions and say whether they changed after reading, and if so, how the book can influence the opinions of other readers. The answers to the second question were to specify the general perception and the kinds of emotion which the novel evokes. The distribution of responses to these questions is presented in Figure 5.

The most important information which can be inferred from the responses is the influence of the book on the perception of the city. For 53\%, reading Lampiony changed their opinion (25\% - for the better, $28 \%$ - for the worse). The respondents' thoughts on its influence on other people are interesting. Here, the statements are less critical, only $19 \%$ perceive a negative tone to the text which, will have a negative influence on other readers. In this case, more people expect a lack of influence of the book on the image of the city (39\%).

This may point to the fact that Łódź is presented unfavourably in the novel. We must not forget about its genre: it is a crime story, a novel full of wrongdoing, violence and other pathologies. The setting itself could not be presented in an idealised way, so that the reader would not detect the lack of authenticity. From the point of view of tourism organisers or city authorities, however, it is worth discussing the promotion of this type of literature. Whether it is for marketing reasons ('The only thing worse than being talked about is not being talked about.') or for

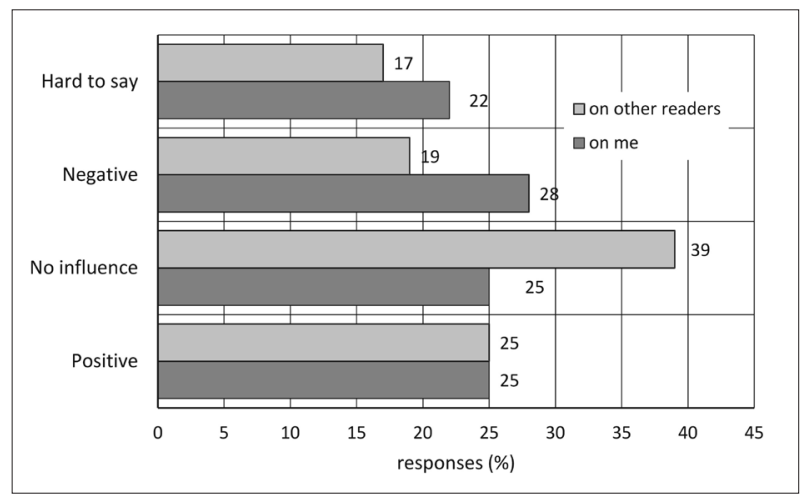

Fig. 5: The influence of reading Lampiony on the image of Łódź. Source: authors' compilation from survey 
tourism, it is not advisable to promote negative associations among potential tourists. A similar situation is found in the case of the crime story entitled Ziarno prawdy (A Grain of Truth) (Miłoszewski, 2014), which presented the setting (Sandomierz) as a provincial town, full of people with complexes. For a substantial period of time, the author was treated as persona non grata and ignored by the town authorities (Pudelko, 2015). The situation changed, however, when it turned out that despite the negative overtones, the book attracted tourists to Sandomierz, and its film adaptation contributed to the promotion.

In order to examine this phenomenon in more detail, respondents were asked to present their opinions about individual elements and aspects of city life before and after reading the novel. It forced them to think more deeply and focus on individual elements, not on the city as a whole. In addition, a question of 'changing opinions' was concealed here, as the respondents evaluated individual components using a 1- scale (from 'definitely negative' to 'definitely positive'). The element of change or lack of opinion was defined ex post, by comparing the respondents' opinions declared 'before' and 'after' reading the book (see Tab. 1).

Before reading Lampiony, the categories rated highest included the development prospects for the city and the number of historical monuments, and those rated lowest were cleanliness and affluence. After reading the novel, the respondents evaluated the number of historical monuments and tourist attractions most positively, and safety and cleanliness most negatively.

Therefore after reading, the average rating for 6 out of 8 evaluated elements decreased, opinions became more critical as regards the city's general appearance, safety (the largest decrease), cleanliness, inhabitants, affluence and development prospects. Reading the book improved opinions regarding only two elements: the number of tourist attractions and historical monuments.

From the point of view of the study, the change of opinions as a result of reading is quite significant, $41 \%$ of the respondents changed their opinion either more positive or more negative, the difference between them being similar. The opinions which changed the most regarded appearance, safety and development prospects (respectively, 68, 62 and 59 respondents changed their opinion, comprising 45-52\%) of the responses. The smallest number changed with respect to the number of historical monuments and the affluence of the city. Looking at the total number of answers, the largest increase was recorded among negative opinions. While before reading the book those responses constituted $27 \%$ of all answers, after reading, it was $37 \%$. This means that reading the book had an influence on changing opinions about the city in nearly half of the respondents and in this case it was a change for the worse.

\section{2 'A city remembered'}

The respondents also answered an open question, they were asked to think of a few words they associated with the city of Łódź after reading the book. In this way, it was possible to learn about their first associations which had not undergone any earlier categorisation or evaluation. This freedom of expression was to guarantee 'true' and more emotional opinions. Short statements were assessed and ascribed to four categories: positive, negative, neutral, and one including contrasts. The fourth category in this case was necessary because it encompasses a relatively large group of responses. Just as the writer stressed in her statements (and in the text of the novel), contrasts exist everywhere in Łódź; in its space, people and emotions. The same could be observed for the respondents' former opinions; in a few cases, the figure evaluating a given phenomenon as positive or negative was very similar. Among the free answers, there were quite a few statements which cannot clearly be ascribed to one of the three 'classical' categories because they represented extreme elements. For such responses a new category of 'contrastive' was proposed. Examples of responses are included in Table 2.

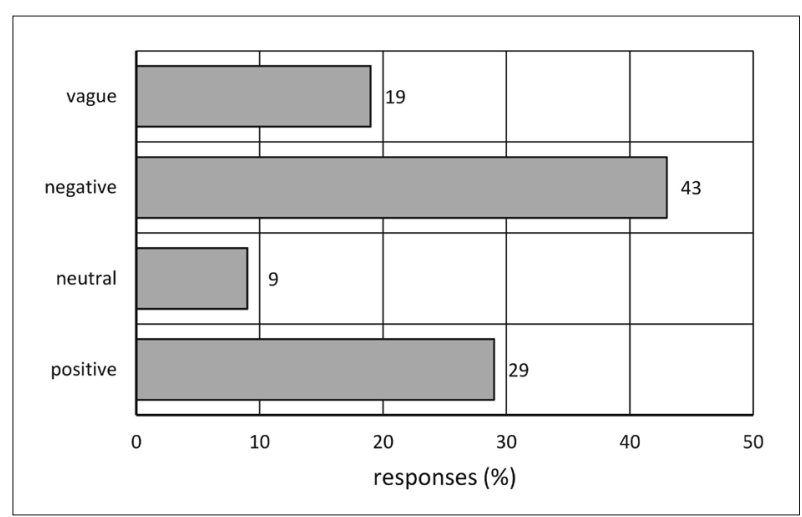

Fig. 6: Connotation of first associations with the city Source: authors' calculations from sample survey

\begin{tabular}{|c|c|c|c|c|c|c|c|c|c|c|c|}
\hline \multirow{3}{*}{ No. } & \multirow{3}{*}{$\begin{array}{l}\text { Evaluated elements } \\
\text { and city life aspects }\end{array}$} & \multicolumn{2}{|c|}{ Average rating } & \multicolumn{8}{|c|}{ Change of opinion (considered individually) } \\
\hline & & \multirow[t]{2}{*}{ before } & \multirow[t]{2}{*}{ after } & \multicolumn{2}{|c|}{ improved } & \multicolumn{2}{|c|}{ got worse } & \multicolumn{2}{|c|}{ no change } & \multicolumn{2}{|c|}{ don't know } \\
\hline & & & & number & $\%$ & number & $\%$ & number & $\%$ & number & $\%$ \\
\hline 1 & Appearance & 3.06 & 3.05 & 36 & 27.7 & 32 & 24.6 & 48 & 37.0 & 14 & 10.7 \\
\hline 2 & Safety & 3.04 & 2.60 & 15 & 11.5 & 47 & 36.2 & 46 & 35.4 & 22 & 16.9 \\
\hline 3 & Number of tourist attractions & 3.16 & 3.40 & 34 & 26.1 & 17 & 13.1 & 55 & 42.3 & 24 & 18.5 \\
\hline 4 & Number of historical monuments & 3.34 & 3.41 & 22 & 16.9 & 13 & 10.0 & 72 & 55.4 & 23 & 17.7 \\
\hline 5 & Cleanliness & 2.77 & 2.67 & 19 & 14.6 & 31 & 23.8 & 55 & 42.1 & 25 & 19.2 \\
\hline 6 & Inhabitants & 3.14 & 2.97 & 21 & 16.1 & 32 & 24.6 & 52 & 40.1 & 25 & 19.2 \\
\hline 7 & Affluence & 2.84 & 2.74 & 16 & 12.3 & 28 & 21.5 & 67 & 51.1 & 19 & 14.6 \\
\hline \multirow[t]{2}{*}{8} & Development prospects & 3.39 & 3.05 & 20 & 15.4 & 39 & 30.0 & 49 & 37.7 & 22 & 16.9 \\
\hline & Total & 3.09 & 2.99 & 183 & 17.6 & 239 & 23.0 & 444 & 42.7 & 174 & 16.7 \\
\hline
\end{tabular}

Tab. 1: Respondents' evaluation of the city. Source: authors' calculations based on the sample survey: percentage of all responses. Average rating: $1.00=$ definitely negative, $3.00=$ neutral, $5.00=$ definitely positive. 


\section{Positive}

"atmospheric, murky, interesting, enigmatic, mysterious, inspiring"

"interesting buildings: beautiful palaces, old tenement houses"

"underrated, original, undiscovered"

"intriguing, captivating"

"interesting, unique, worth visiting"

"modernity mixed with tradition, friendly people"

\section{Negative}

"bums, criminality, hopelessness, demise"

"filth, poverty, hopelessness"

"bad city with bad people"

"damaged, dying, a city without perspectives"

"a city of bums, infantile bums... Not very good promotion, I think..."

"dark, old city"

"a ruined, dying city without perspectives"

"a city full of psychos and criminals"

\section{Neutral}

"strange city, strange novel"

"an industrial city, an industrial landscape"

"a city of tenement houses and factories"

"completely nothing stuck in my memory"

\section{Contrastive}

"tenement houses falling apart, canals under the city, the homeless, bohemian artists, hip hop"

"a city of contrasts, fascinating, run down, a city of many mysteries"

"multiculturality, uniqueness, diversity, inconspicuousness, neglect, extremes (poverty - wealth), wasted / unused potential"

"a city of bums, but at the same time multicultural"

Tab. 2: Examples of readers' (respondents') statements

Source: authors' compilations based on survey research results

After applying this classification, it turned out that neutral responses made up only 9\% of all answers (see Fig. 6). This proves a strong emotional involvement on the part of readers as the book hardly ever left them unaffected. It evoked strong, often ambivalent emotions (every fourth reader). This shows that it is an effective way of reaching the reader, if we treat a book about the city as an advertisement, because the time spent in the imagined space (in this case largely corresponding to the real one) is much longer than with other forms of promotion. It seems that the reader becomes 'immersed' in the story and completely gives herself/himself to it. She/he is more susceptible to the writer's suggestions and the messages coming from literature. The reader remembers more and, what is important, believes in it more strongly than in the case of traditional forms of tourist site promotion.

\subsection{Literary fiction versus reality}

As indicated above, the book presents several dozen real sites, often with descriptions, and that is why respondents were asked to list places which they remembered from the novel. We can speak of a promotional success of Lampiony here because as many as 80 out of 130 respondents mentioned at least one place, and the 'record breaker' mentioned eight.
The average was 2.6. The most popular included Piotrkowska St, the district of Bałuty, underground tunnels and canals (it is interesting as the tunnels exist only in the writer's imagination, while the large network of sewers is by all means real), the central tram terminal, historic hotels where the characters from the book were staying (burnt down by the psychopath from the story), and actually existing tenement houses and factories. It is not surprising that the readers remembered places which were important for the plot, those where the action took place and those which were most deeply described by the writer. It is strange, however, that some places described in much detail were mentioned by only a few. This means that it is not the length of the description that makes the reader remember a given place, or that the places described by the writer in so much detail were not significant from the reader's point of view.

The readers rated the descriptions of place included in the book as realistic, while the realism of the plot and situations in the novel were rated a little lower (see Fig. 7).

Readers' high evaluations of the level of realism in the descriptions has an influence on how much they trust the writer. The readers feel that despite the fact that the novel

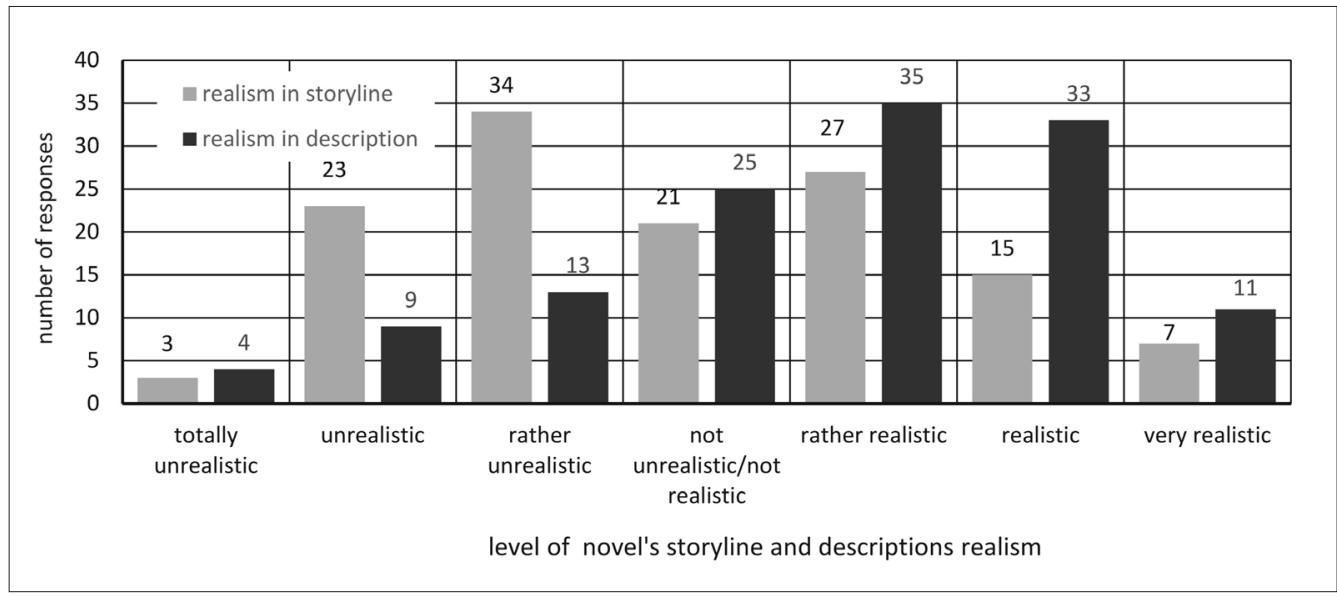

Fig. 7: Evaluating the realism of the descriptions of the city and storyline in the novel Source: authors' compilations from sample survey 
is fictitious, many of its elements (mainly the setting) look exactly the same in reality as on the pages of Lampiony. Such faithful descriptions allow the writer to 'smuggle' fiction, unnoticeable for a reader unfamiliar with the city, into the truth. In this case, the fiction included the underground tunnels which do not exist in reality. Some readers believed they were real and even mentioned them as places which they would like to visit in the city. The stronger the readers' belief that a description is realistic, the stronger its promotional effect (intentional or not) becomes, or quite to the contrary, the stronger the depreciation of the real place. Thus, the credibility of the story and the content is very important as regards the perception of the real place by the readers.

It is worth noting that respondents living in Łódź expressed a clearly different opinion. It was the only difference between them and other readers. A low evaluation, for instance, of the realism of descriptions or holding the opinion that the book had a negative influence on the promotion of the city, can be the starting point for interesting future research on the perception of the city. The author's writing skills are probably evaluated differently when someone knows the described places from their own experience than when they only imagine them based on literature. Perhaps, it is also related to the observations made by Reijnders (2015), in which readers 'see' the story not through the writer's descriptions, but through their strongly rooted associations with, or memories of places from, childhood, which had strongly impressed them. In this case, the inhabitants 'read the book through images' which they see every day, and those who do not know the city read it through their imagination, to a lesser or greater extent giving in to the writer's intentions.

The respondents were also asked to specifically on two issues, most important from the point of view of literary tourists. They were asked whether they were planning to visit Łódź under the influence of the book (Fig. 8), and if so, what they would like to see there.

Here, the respondents' opinions differed again. The number who wanted to visit the city was similar to those who did not. More than one-third of respondents (nearly 36\%) who answered this question declared an intention to visit Łódź. Considering the rather negative image of the city emerging from the respondents' statements, this could be regarded as a good result. A similar percentage of respondents declared 'neutrality' and did not think that Lampiony had changed anything in their attitude to Łódź. Perhaps the factor responsible for this opinion was an increasing awareness of the historical monuments and tourist attractions presented

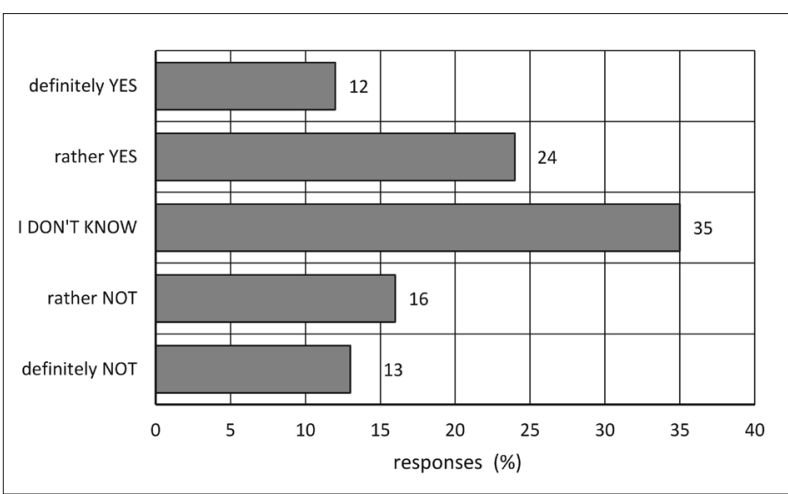

Fig. 8: The choice of Łódź as the destination of a planned tourist trip after reading the book Source: authors' compilations from sample survey in the analyses of individual elements of the city's image. It is possible that readers could be persuaded to visit Łódź by the 'contrastive' and, consequently, original atmosphere of the city, presented in the novel. This hypothesis may be confirmed by an analysis of the places indicated by the respondents as those which they would like to visit. Common answers included 'the whole city', 'to feel this atmosphere', 'you should visit the whole city, not only some parts'. The most commonly mentioned specific place is the main street, Piotrkowska, (the readers had probably heard about it before reading the novel), historical tenement houses and the underground canals, where a large part of the action takes place and which are not open for visiting (apart from the museum, where some of the action also takes place).

\subsection{Major determinants of visiting Łódź}

For more detailed analysis concerning the probability of readers visiting Łódź, a general linear modelling approach was used. Regression analysis included only the responses of participants living outside Łódź $(\mathrm{n}=120)$. A large set of independent variables were analysed: whether the respondent had ever been to the city (yes/no); the first association after reading the book (positive/negative); familiarity (any knowledge/no knowledge); change of attitude (the book changed/did not change opinions about the city: respondent's declaration); direction of change (for better/ for worse); living in a large city (over 300,000 inhabitants: yes/ no); remembered places (the respondent mentioned/ did not mention places remembered from the novel); evaluating the realism of the descriptions in the book (realistic/unrealistic); evaluation of the storyline (positive/negative); whether the reader is the writer's fan (yes/no); and sex (female/male).

From the set of 11 independent variables, four were found to be statistically significant: 'large city', 'first association', 'change of opinion' and 'direction of change'. Due to the strong correlation between the latter two, the less explanatory variable ('direction of change') was subsequently excluded from the model. Due to the binary character of the variables (values 0 or 1 ), a logistic regression model was specified.

The dependent variable was 'planned trip to Łódź'. It was the reader's declaration whether they were planning to visit the city in the near future (implicitly after reading Lampiony). Value ' 1 ' was ascribed to 'YES' and '0' to 'NO'.

As regards the significant independent variables, the codes ' 0 ' and ' 1 ' were as follows:

- 'large city': ' 1 ' = the respondent lives in a large city (over 300,000 inhabitants), ' 0 ' = the respondent lives in a small town or the countryside;

- 'first association': ' 1 ' = positive association, ' 0 ' = negative association;

- 'change of opinion': ' 1 ' = the respondent declares that after reading the book, she/ he changed opinions on Łódź (to positive or negative), ' 0 ' $=$ the respondent did not change opinions after reading the novel.

When this reduced set of independent variables is used in the analysis, the logistic regression model is significant (see Table 3).

The interpretation of the results leads to the following conclusions:

- Respondents living in 'Large cities' declared their willingness to visit Łódź more rarely. The value for the $\operatorname{Exp}(B)=0.271$ coefficient means that approximately in 


\begin{tabular}{lrccccc}
\hline Change of opinion & B & Std. deviation & Wald test & df & Sig. & $\operatorname{Exp(B)}$ \\
\hline Association & 2.489 & 0.487 & 26.085 & 1 & 0.000 & 12.051 \\
Large city & -1.307 & 0.492 & 7.067 & 1 & 0.008 & 0.271 \\
Change of opinion & 1.214 & 0.491 & 6.105 & 1 & 0.013 & 3.367 \\
Constant & -1.560 & 0.510 & 9.349 & 1 & 0.002 & 0.210 \\
\hline
\end{tabular}

Tab. 3: Logistic regression for the dependent variable: 'a planned visit in the city' Source: authors' calculations using SPSS software

the case of every third person, the place of residence has a significant influence on taking a decision concerning a potential visit to the city;

- A positive 'Association' has the most positive influence on the decision to visit the city (the value of $\operatorname{Exp}(\mathrm{B})$ is over 12 , which means that a positive association results in a decision to visit the city over 12 times more often than a decision not to); and

- The declared 'Change of opinion' about the city has a positive influence on the declaration to visit. The value of the $\operatorname{Exp}(B)$ coefficient higher than ' 3 ' means that the decision to visit was made three times more often among those who admitted that the book had changed their opinion about the city. This change is particularly significant from the point of view of the discussion about the role of the book in shaping the decision concerning the choice of the tourist destination. It shows that such a relationship does exist and the role of the novel in shaping opinions about the city to a certain extent influences the plans for a trip.

For this model, the results (Chi-square $=52,025$ and significance $>0.0001)$ confirm its significance. The coefficients of fitting the model to Cox and Snell's R-square data and to maximally corrected R2 - Nagelkerke, at the level of 0.352 and 0.477 , indicate a good fit. Expressed relatively, these results show that the decision to visit Łódź will probably be taken by those from smaller places (small towns and villages), who might have changed their opinion about the city under the influence of the book, and that likely their first association with Łódź after reading was positive. This means that if Łódź authorities want to use Lampiony for promotion, it would be reasonable to run an advertising campaign in smaller towns rather than in large cities (different from before when the publisher's advertising campaign was run in cities). From the point of view of attracting tourists to the city, it would probably be better to buy a copy of the book for village and town libraries than to run an expensive billboard campaign in the capital.

\section{Conclusions and recommendations}

Literary tourism is growing in popularity. There are more and more academic publications on this form of tourism, but only a few concern research on the influence of reading a literary work on the motivation to choose specific destinations.

Many studies have demonstrated that novels whose action is set in real, specific places have a considerable influence on shaping the image of these places, but it is not always a desired (positive) image, which might result in readers visiting the city. The following factors are important in this process: the reader's place of residence; earlier stereotypes concerning the city (and whether they have been confirmed or changed by the descriptions included in the novel); as well as attractive, unknown places and facts presented in the book. We must not forget, however, any reader's individual approach to the work, visible in their extreme feelings, emotions and opinions.

From the point of view of the objectives set for this paper, it is important to note that reading the novel has had a positive influence on making the decision to visit the city (in this case Łódź) by people living in small towns, who had changed their opinion after reading the novel. This conclusion is confirmed by both the detailed qualitative analyses of the responses, and by the statistical methods used. It would be interesting to check whether this relationship also applies to the inhabitants of large cities who read such novels set in smaller places.

It should be remembered, however, that depending on the author's intentions and vision, as well as the character of the content included in the descriptions (authenticity, naturalness, emotionality), the final effect may vary from delight to extreme disgust. Therefore, city promotion taking advantage of 'grim' novels (such as Lampiony) is risky and may bring results quite different from expected.

Considering the originality of these analyses based on research conducted among readers, potential tourists, as well as any effects of the actual influence of literature on the choice of destination, it is worth recommending similar comparative studies concerning other novels set in specific locations. The variables in such future research should be not only the locations (their size, character and brand), but also different literary genres. This will make it possible to compare the results, both in spatial and problem-related aspects. It is important for any such study to be conducted among readers who are not directly familiar with the place described in the book, as in this case of "Lampiony". One of the results might be an investigation of to what extent a literary work can be the basis for creating not only a new, attractive tourist product, but also a whole image of a city as an interesting tourist destination.

\section{References:}

ADLER, J. (1989): Origins of sightseeing. Annals of Tourism Research, 16(1): 7-29.

ANDERSEN, H. C., ROBINSON, M. [eds.] (2002): Literature and tourism - reading and writing tourism texts. London, Continuum.

BONDA, K. (2016): Lampiony. Warszawa, Muza.

BUSBY, G., KLUG, J. (2001): Movie-induced tourism: The challenge of measurement and other issues. Journal of Vacation Marketing 7(4): 316-332.

BUTLER, R. (2000): Literary tourism. In: Jafari, J. [ed.]: Encyclopedia of tourism. London.

COSMA, S., POP, C., NEGRUSA, A. (2007): Should Dracula Myth be a brand to promote Romania as tourist Destination? Interdisciplinary Management Research 3: 39-56. 
DUNG, Y., REIJNDERS, S. (2013): Paris off-screen: Chinese tourists in cinematic Paris. Tourist Studies 13(3): 287-303.

ECHTMER, C., RICHIE, J.R.B. (2003): The meaning and measurement of destination image. The journal of tourism studies 14(1): 37-48.

ELLIS, B. (1989): Death by Folklore: Ostension, Contemporary Legend, and Murder. Western Folklore 48(3): 201-20.

ELLIS, B. (2001): Aliens, Ghosts, and Cults: Legends We Live. Jackson, University Press of Mississippi.

FAWCETT, C., MCCORMACK, P. (2001): Guarding authenticity at literary tourism sites. Annals of Tourism Research, 28(3): 686-704.

FLEMING, M. (2012): Legitimating Urban 'Revitalisation' Strategies in Post-socialist Łódź. East European Politics and Societies, 26(2): 254-273.

GENTILE, R., BROWN, L. (2015): A life as a work of art: literary tourists' motivations and experiences at Il Vittoriale Degli Italiani. European Journal of Tourism, Hospitality and recreation, 6(2): 25-47.

HALL, C. (2014): Poland's Detroit: Life and games in Poland's third largest city [online]. [cit. 20.06.2018]. Polygon. Available at: http://www.polygon.com/ features/2014/7/16/5888655/poland-detroit-lodz

HENDRIX, H. (2009): From early modern to romantic literary tourism: a diachronical perspective. In: Watson, N. J. [ed.]: Literary Tourism and Nineteenth-Century Culture (pp. 13-24). Basingstoke, Palgrave Macmillan.

HERBERT, D. (2001): Literary places, tourism and the heritage experience. Annals of tourism Research, 28(2): 312-333.

HOPPEN, A., BROWN, L., FALL, A. (2014): Literary tourism: Opportunities and challenges for the marketing and branding of destinations? Journal of Destination Marketing \& Management 3: 37-47.

HUDSON, S., RITCHIE, J. R. B. (2006): Promoting destinations via film tourism, an empirical identification of supporting marketing initiatives. Journal of travel research 44(1): 387-396.

JIANG, L., XU, H. (2017): The growth of literary places in ancient town tourism destinations: based on the theories of Bourdieu, Danto and Dickie. Journal of Tourism and Cultural Change, 15(3): 213-228.

KAVARATZIS, M., ASHWORTH, G. J. (2006): City Branding: An Effective Assertion of Identity or a Transitory Marketing Trick? Place Branding 2(3): 183-194.

KELLY, G. (2008): Set Jetting. New York Post $19^{\text {th }}$ February 2008.

LEE, Y., WEAVER, D. (2012): The tourism area life cycle in Kim Yujeong Kiterary village, Korea. Asia Pacific Journal of Tourism Research, 19(2): 181-198.

LI, S., LI, H., SONG, H., LUNDBERG, C., SHEN, S. (2017): The economic impact of on-screen tourism: The case of The Lord of the Rings and the Hobbit. Tourism Management 60: 177-187.

LISZEWSKI, S. (1997): Functional and Spatial Changes in the Industrial Districts of the City of Łódź. In: Liszewski S., Young, C. [eds.]: A Comparative Study of
Łódź and Manchester. Geographies of European Cities in Transition (pp. 57-72). Łódź University Press.

LIGHT, D. (2007): Dracula tourism in Romania. Cultural Identity and the State. Annals of Tourism Research, 34(3): 746-765.

MANSFIELD, C. (2015): Researching Literary Tourism. , Bideford, Shadows Books \& Media.

MARCIŃCZAK, S., SAGAN, I. (2011): The Socio-spatial Restructuring of Łódź, Poland. Urban Studies, 48(9): 1789-1809.

MARTIN-JONES, D. (2014): Film tourism as heritage tourism: Scotland, diaspora and the Da Vinci Code. New Review of Film and Television Studies, 12(2): 156-177.

MCGUCKIN, M. (2015): Literary Tourism - What can we learn from Shakespeare's Birthplace? Paper presented at the $11^{\text {th }}$ Annual Tourism \& Hospitality Research in Ireland (THRIC 2015) conference. 11-12 June [online]. [cit. 02.02.2018]. Available at: https://research.thea.ie/ handle/20.500.12065/1215

MIŁOSZEWSKI, Z. (2014): Ziarno prawdy. Warszawa, W.A.B. MINTEL GROUP (2010): Cultural and heritage tourism international - May. London. Mintel International Group.

MINTEL GROUP (2011): Literary tourism - international September, London, Mintel International Group.

NATIONAL GEOGRAPHIC (2011): Top 10 Literary Cities [online]. [cit. 19.07.2018]. Available at: http://www. nationalgeographic.com/travel/top-10/literary-cities

PIKE, S., RYAN, C. (2004): Destination positioning analysis through a comparison of cognitive, affective and conative perceptions. Journal of Travel Research 42(1): 333-342.

Postrzeganie miast wojewódzkich (2013): TNS OBOP [online]. [cit. 06.11.2017]. Available at: http://www. tnsglobal.pl/wp-content/blogs.dir/9/files/2014/03/K.077_ Postrzeganie-miast-wojewodzkich_008a-13.pdf

PUDEŁKO, A. (2015): Zbrodnia w mieście - turystyka literacka śladami powieści kryminalnych. Turystyka kulturowa 10: 38-57.

REIJNDERS, S. (2011): Places of the Imagination: Media, Tourism, Culture. Farnham, Ashgate Publishing.

REIJNDERS, S. (2015): Stories that move: Fiction, imagination, tourism. European Journal of Cultural Studies, 19(6): 672-689.

Reputacja miast wojewódzkich (2015): Premium Brand [online]. [cit. 06.11.2017]. Available at: http://www. premiumbrand.com.pl/wp-content/uploads/2014/09/ Premium-Brand-2016_miasta_raport_24-02-2016_ short.pdf

RODRIGUEZ, C. (2015): 'Game Of Thrones' Is Transforming Croatia Into a 'Kingdom Of Tourism' and Set-Jetting. Forbes [online]. [cit. 06.11.2017]. Available at: https:// www.forbes.com/sites/ceciliarodriguez/2015/03/30/gameof-thrones-is-transforming-croatia-into-the-kingdom-oftourism/\#77016aab3b36

RYAN, C., YANNING, Z., HUIMIN, G., SONG, L. (2009): Tourism, a Classic Novel, and Television - The Case of Cáo Xuěqin's Dream of the Red Mansions and Grand View Gardens, Beijing. Journal of Travel Research, 48(1): 14-28. 
SKYSCANNER (2009): The trail of the Lost Symbol: how Dan Brown is boosting tourism [online]. [cit. 09.11.2017]. Available at: https://www.skyscanner.net/news/trail-lostsymbol-how-dan-brown-boosting-tourism

SMITH, Y. (2012): Literary tourism as a developing genre: south Africa's potential. Pretoria, University of Pretoria.

SQUIRE, S. J. (1991): Meanings, myths and memories: literary tourism as cultural discourse in Beatrix Potter's lake district. London, University of London, University College London.

SQUIRE, S. J. (1994): The cultural values of literary tourism Annals of Tourism Research, 21(1): 103-120.

STASIAK, A. (2009): Turystyka literacka i filmowa. In: Buczkowska K., Mikos von RohrscheidtA. [eds.]: Współczesne formy turystyki kulturowej (pp. 223-265). Poznań.

STAN CZYTELNICTWA W POLSCE w 2015 roku (2016): Biblioteka Narodowa [online]. [cit. 06.11.2017]. Available at: https://www.bn.org.pl/download/document/1459845698.pdf

TOWNER, J. (2002): Literature, tourism and the Grand Tour. In: Robinson, M., Anderson H. C. [eds.]: Literature and Tourism: Reading and Writing Tourism Texts (pp. 226-238). London, Continuum.
WALLACE, C. (2009): Yeats's country and 'Yeats Country': conceptualizing literary spaces. Journal of Tourism and Cultural Change 7: 48-60.

WATSON, C., SAUNDERS, R. (2004): The production of literary landscapes. In: Robinson, M., Picard, D. [eds.]: Conference proceedings tourism and literature: travel, imagination and myth, 22-26 July 2004, Harrogate. CDROM, Sheffield, Centre for Tourism and cultural change.

WATSON, N. J. (2006) The literary tourist. Basingstoke, Palgrave Macmillan.

World Tourism Organization (2005): City tourism and culture: The European experience. A report of the World Organization and of the research group of the European Travel Commission. Madrid, Spain.

YOUNG, C., KACZMAREK, S. (2008): The socialist past and post-socialist urban identity in central and eastern Europe. The case of Łódź, Poland. European Urban and Regional Studies 15(1): 53-70.

\section{Please cite this article as:}

WŁODARCZYK, B., DUDA, M.(2019): The role of the novel in shaping a city's image and its choice as a tourist destination: The case of Łódź. Moravian Geographical Reports, 27(1): 41-53. Doi: 10.2478/mgr-2019-0004. 